\title{
NUTRITIONAL EVALUATION OF SOME CROP RESIDUALS AS A ROUGHAGE SOURCES FOR FEEDING LAMBS El-Bordeny, N.E. ${ }^{1}$ and Ebtehag I. M. Abou - Elenin ${ }^{2}$ 1- Animal Prod. Dept., Fac. of Agric. Ain Shams University, Egypt 2- Animal Nutrition Dept., Animal Prod. Res. Inst. (APRI), Dokki, Giza.
}

\begin{abstract}
Twenty four Rahmany male lambs $(25.6 \pm 1.69 \mathrm{~kg}$; four months age) were divided into three similar groups, eight animals each. The animals were randomly assigned using a complete randomize design to receive one of the three rations as following for 90 day. All animal fed concentrate feed mixture at rate of $2 \%$ of live body weight and had ad libitum access to Faba bean straw (G1), Chick-pea straw (G2) and Lentil straw (G3). At the middel of the experimental period, three digestion trails were carried out by using metabolic cages to determine nutrients digestibility, nitrogen balance and feeding values of experimental rations. Data obtained revealed that Lentil and Chick-pea straws were higher OM, CP and NFE content than faba bean straw. On the other hand, the same straws were less ash and crude fiber content compared to Faba bean straw. Ration containing Lentil straw and chick-pea straw had significantly higher $(\mathrm{P}<0.05)$ crude protein intake $(\mathrm{CPI})$ and total digestible nutrients intake (TDNI) as well as digestible crude protein intake (DCPI). In addition to DM, CF and NFE digestibility for ration $G 3$ were $(P<0.05)$ higher than $G 1$ and $G 2$. Concerning the nutritive values as TDN and DCP the results showed that $G 3$ was higher $(\mathrm{P}<0.05)$ than $\mathrm{G} 1$ and $\mathrm{G} 2$. Insignificant differences $(\mathrm{P}>0.05)$ were noticed in rumen $\mathrm{NH}_{3}-\mathrm{N}$ after 6 hrs feeding and TVFA's concentration among the groups at times 0 and 3 hrs after feeding. While, values of $\mathrm{pH}$ had significant higher in $\mathrm{G} 3$ after 3 and 6hrs feeding than $\mathrm{G} 1$ and $\mathrm{G} 2$. Nitrogen balance data clearly indicated that $\mathrm{N}$ retention was higher $(P<0.05)$ for $G 3$ and $G 2$ comparable $G 1$. Significant $(P<0.05)$ increase in blood total protein, albumin and globulin concentration was recorded for $\mathrm{G} 3$ and $\mathrm{G} 2$ compared to G1. Lentil straw group (G3) had the highest total gain and average daily gain (ADG) being $16.0 \mathrm{~kg}$ and $178 \mathrm{gm}$, respectively, at the same time, feed conversion as $\mathrm{kg}$ $\mathrm{DM} / \mathrm{kg}$ gain improved. While, Chick pea was more economic efficiency than Lentil straw (G3) and Faba bean straw (G1). However, ration containing Chick pea straw had cheaper cost for produce $1 \mathrm{~kg}$ gain than the others. So, it could be concluded that, chick pea straw and lentil straw had to be used as a good roughages in rations of growing lambs.
\end{abstract}

Keywords: Legume straws; Lentil straw; Faba bean straw ;Chick-pea straw; digestibility; nitrogen balance; lambs.

\section{INTRODUCTION}

Ruminant livestock in tropics and sub-tropics receive most of their dietary needs from native pasture and crop residues (Mekasha, et al., 2002). By-product and crop residuals are becoming more important in livestock feeding system because of its cheaper price and more availability for use at competitive prices relative to other commodities (Grasser et al., 1995).

Recently, prices of concentrate feedstuffs increased dramatically. Feeding is the most important cost item for livestock production which represents about $70 \%$ of the total production costs in Egypt (Borhami and 
Yacout 2001); therefore, more attention was given to agro industrial byproducts.

The agricultural by-products considered as stable source of ruminant feeds and nowadays interest in their effective utilization is increasing all over the world due to economical factors and pollution.

Non traditional feed resources such as crop residues and Agroindustrial by-products must searched in order to decrease the relay on traditional resources to fill the gap and to decrease feeding costs (Zaza, 2005). In Egypt the annual agriculture by-products estimated to be around 30 million tons of dry material (Nawar, 2007). Approximately two thirds of the crop residues are burned or wasted, and hence lead to environmental pollution and consequently health hazards. Utilization of such by-product can not only be used in favor of solving feed shortage problem but also as a method to control environmental pollution (Zaza, 2004).

In the extensive Mediterranean production systems, fibrous feeds, particularly cereal straws and stubbles, are the most important diet ingredients for ruminants. Therefore, it is necessary to evaluate the nonconventional feed resources that can use as animal feeds. A wide variety of arable legume crops are grown on Upper Egypt. Many of these crops have residues which can form an important source of livestock feed, following grain harvest, such as chick-pea straw and lintel straw.

Although quantitatively less important, legume straws can represent a valuable feed resource for those animals. The available information on the nutritive value of legume straws is scarcer in case of cereal straws or grass hays (Bruno-Soares et al., 2000). So the objective of this study was to evaluate the nutritive values of these crop residues as will as study the effect of its inclusion in ration on lamb performance compared to Faba bean straw.

\section{MATERIALS AND METHODS}

The present study was carrid out at Agriculture Experimental and Research Center belong to Faculty of Agriculture, Ain Shams University and Department of Animal Nutrition, Animal Production Research Institute, Agriculture Research Center, Ministry of Agriculture.

\section{Animals and feeding}

Twenty four Rahmany male lambs (4 months, age) with mean initial live body weight of $25.6 \pm 1.69 \mathrm{~kg}$, were chosen and divided into three similar groups, eight animal each. The animals were randomly assigned to receive one of the three rations as following for 90 days.

Group1 (G1): Commercial concentrate feed mixture (CFM) at rate of $2 \%$ of live body weight + Faba bean straw ad-lib.

Group2 (G2): CFM + Chick pea straw ad-lib.

Group3 (G3): CFM + Lentil straw ad-lib.

The concentrate portion was offered to animals in two equal meals twice daily $(8.00$ am and $3.00 \mathrm{pm}$ ), the amount of CFM offered was adjusted biweekly for each group according to increase in body weight. Also the straws were added ad lib for each group, the residual amount of offered roughage were determined. 
Each group was kept in separate shaded pen and feeding as group. Fresh water and salt blocks were available for each group through all the day. Animal were weighed biweekly, while feed consumption, live weight gain, feed conversion and feed costs/kg live body weight gain were calculated accordingly.

\section{Metabolism trials:}

At the middle of the experimental period. Three digestibility trials were carried out by using three lambs each to determine nutrients digestibility, feeding values and nitrogen balance of tested ration by using metabolic cages. Sample of rumen fluids were collected from each animal at zero, 3 and $6 \mathrm{hr}$ post feeding by stomach tube at the end of the digestibility trial to determine some ruminal parameters.

The lambs were individually fed in metabolism cages (in digestion trials), water was available free. The trial extended for 15 days, adaptation period lasted for 10 days and collection period lasted for 5 days. Feces and urine were collected quantitatively daily during the collection period as described by Maynard et al., (1979). Solution of $10 \% \mathrm{H}_{2} \mathrm{So} 4$ was added to the representative feces samples before drying in oven at $60{ }^{\circ} \mathrm{C}$ for $24.00 \mathrm{hrs}$. Dried samples were ground and kept for chemical analysis. $50 \mathrm{ml}$ diluted sulfuric acid (10\%) was butted in urine collect containers each day. A representative samples (10\%) of urine volume stored for nitrogen determination.

\section{Blood samples}

Blood samples were taken at $2 \mathrm{hrs}$ post morning feeding from 3 animals of each group. Blood serum was obtained by centrifuging the blood samples soon after collection at 4000r $/ \mathrm{min}$ for 15 minutes. The blood serum was transferred into clean dried glass vials and then stored in deep freezer at $20^{\circ} \mathrm{C}$ for subsequent specific chemical analysis.

\section{Analytical methods}

Samples of feedstuffs and feces were taken and air dried at $55 \mathrm{C}^{\circ}$ for 48 hour in forced air oven up to about $10-12 \%$ moisture, then it kept to subsequent analysis. Dried samples were ground through a Wiley Mill fitted with a $1 \mathrm{~mm}$ screen and chemically analyzed according to AOAC (1995) while NFE content was calculated by difference. Urine samples were subjected to nitrogen $(\mathrm{N})$ determination according to AOAC (1995). Ruminal $\mathrm{pH}$ was immediately determined before rumen liquor was stored with a digital $\mathrm{pH}$ meter ( $\mathrm{pHep}{ }^{\circledR}$, pocket-sized $\mathrm{pH}$ meter Hana instruments, Italy). Concentration of $\mathrm{NH}_{3}-\mathrm{N}$ was immediately determined using micro-diffusion method of Conway (1963). Frozen rumen liquor samples were analyzed for total volatile fatty acids (TVF's) by steam distillation according to Warner (1964).

Serum total protein (TP) was determine as described by Armstrong and Carr (1964), while albumin was determined as described by Doumas et al. (1971). Serum globulin (G) was calculated by difference between the TP and Albumin (A) concentration. A:G ratio was calculated.

\section{Statistical Analysis:}


Data were statistically analyzed by using system User's Guide, (SAS, 1998). Separation among means was carried out by using Duncan's multiple range test (Duncan, 1955). The model used was as follows:

$$
Y_{i j}=\mu+T_{i}+e_{i j}
$$

Where: $Y_{i j}=$ experimental observation

$\mu=$ general mean of treatments

$\mathrm{T}_{\mathrm{i}}=$ Effect of treatment

$\mathrm{e}_{\mathrm{ij}}=$ experimental error

\section{RESULTS AND DISCUSSION}

\section{Chemical composition:}

Data presented in Table (1) indicated that Lentil and Chick-pea straws were higher in OM, CP and NFE than faba bean straw; on the other hand, the same previous straws were less ash and crude fiber content compared to faba bean straw. This results was quit similar to Soliman et al., (2005) who found that the Chick-pea straw contained 88.1, 93.48, 11.31, 33.7, 1.9, 46.5 and 6.5 for DM, OM ,CP, CF, EE, NFE and ash, respectively. Abbeddou et al., (2010) told that the lentil straw investigated contained about twice as much CP as the barley straw where, Lentil straw fell within range of 95 to $129 \mathrm{~g} \mathrm{cp} / \mathrm{kg} \mathrm{DM}$. The level CP was slightly higher than the value of approximately $80 \mathrm{~g} / \mathrm{kg}$ published by Haddad and Husein (2001) and is in the range of 43 to $111 \mathrm{~g} / \mathrm{kg}$ DM reported by López et al.(2005).

Table (1): Chemical composition of tested feed ingredients.

\begin{tabular}{|l|c|c|c|c|c|c|c|}
\hline \multirow{2}{*}{\multicolumn{1}{c|}{ Item }} & \multirow{2}{*}{ DM } & \multicolumn{7}{c|}{ \% on DM basis } \\
\cline { 3 - 8 } & & OM & CP & CF & EE & Ash & NFE \\
\hline CFM $^{*}$ & 90.60 & 87.50 & 13.20 & 13.15 & 3.30 & 12.50 & 57.85 \\
\hline Faba bean straw & 91.20 & 83.80 & 4.60 & 37.50 & 1.25 & 16.20 & 40.45 \\
\hline Chick-pea straw & 87.60 & 94.10 & 8.10 & 32.80 & 1.70 & 5.90 & 51.50 \\
\hline Lentil straw & 87.81 & 92.65 & 9.21 & 30.43 & 0.30 & 7.35 & 52.71 \\
\hline Experimental ration: & & & & & & & \\
\hline Group1 (G1) & 100 & 85.71 & 9.06 & 24.88 & 2.31 & 14.29 & 49.46 \\
\hline Group2 (G2) & 100 & 90.67 & 10.75 & 22.58 & 2.54 & 9.33 & 54.80 \\
\hline Group3 (G3) & 100 & 89.95 & 11.30 & 21.37 & 1.87 & 10.05 & 55.41 \\
\hline
\end{tabular}

*Ingredients of CFM: yellow corn $60 \%$, soybean meal (44\%) $7.5 \%$, wheat bran $20 \%$ undecorticated cottonseed meal $10 \%$, mineral mixture $0.5 \%$, salt $1 \%$ and limestone $1 \%$.

Abreu and Bruno-Soares (2008) stated that chick-pea and lintel straw contained similar values for ash\% (4.7 0.84 and $7.0 \pm 2.1 \%)$, but lower CP\% $(5.0 \pm 0.66$ and $8.6 \pm 1.3 \%)$ and higher CF\% (50.6 \pm 1.5 and $41.8 \pm 3.4 \%)$, respectively than that obtained herein. Bruno-Soares et al. (2000) reported that the chemical composition of the legume straws varied from 4.3 to $10.1 \%$ for ash, 6.1 to $16.4 \%$ for $\mathrm{CP}$

In addition, Haddad and Husein (2001) observed that Lentil straw is higher in CP concentration than wheat straw and is more like alfalfa hay in nutrient.

Nutrients digestibility: 
The data presented in Table (2) showed that $\mathrm{G} 3$ had significantly $(P<0.05)$ higher DM and NFE digestibility than $G 1$ and $G 2$, while the value of $\mathrm{OM}$ digestibility for $\mathrm{G} 2$ was higher $(P<0.05)$ than $\mathrm{G} 1$ and $\mathrm{G} 3$. Also, tested ration containing Lentil straw (G3) was $(P<0.05)$ higher $C F$ digestibility than which containing Faba bean straw (G1). On the other hand G3 recorded insignificant increase of $\mathrm{CP}$ and EE digestibility compared to G1, while, G2 tended to higher and lower insignificant of $C P$ and $E E$ digestibilities, respectively than $\mathrm{G} 1$.

Table (2): Effect of experimental treatment on nutrients digestibility and nutritive value of tested rations (\%) with sheep.

\begin{tabular}{|l|c|c|c|c|c|}
\hline \multicolumn{1}{|c|}{ Item } & G1 & G2 & G3 & $\begin{array}{c}\text { Overall } \\
\text { mean }\end{array}$ & SE \\
\hline Nutrients digestibility(\%): & & & & & \\
\hline DM & $59.92^{\mathrm{b}}$ & $61.65^{\mathrm{b}}$ & $68.58^{\mathrm{a}}$ & 63.38 & \pm 1.16 \\
\hline $\mathrm{OM}$ & $61.17^{\mathrm{b}}$ & $68.18^{\mathrm{a}}$ & $63.65^{\mathrm{b}}$ & 64.33 & \pm 1.19 \\
\hline $\mathrm{CP}$ & 68.57 & 68.78 & 71.78 & 69.71 & \pm 1.52 \\
\hline $\mathrm{CF}$ & $55.4^{\mathrm{b}}$ & $60.6^{\mathrm{a}}$ & $61.6^{\mathrm{a}}$ & 59.20 & \pm 1.71 \\
\hline EE & 65.63 & 62.97 & 65.67 & 64.76 & \pm 1.28 \\
\hline NFE & $62.33^{\mathrm{b}}$ & $66.43^{\mathrm{b}}$ & $71.67^{\mathrm{a}}$ & 66.81 & \pm 1.27 \\
\hline $\begin{array}{l}\text { Nutritive value (\%): } \\
\text { TDN }^{\star}\end{array}$ & $54.24^{\mathrm{c}}$ & $61.01^{\mathrm{b}}$ & $63.75^{\mathrm{a}}$ & 59.67 & \pm 0.45 \\
\hline $\mathrm{DCP}^{\text {D }}$ & $6.21^{\mathrm{c}}$ & $7.39^{\mathrm{b}}$ & $8.11^{\mathrm{a}}$ & 7.24 & \pm 0.19 \\
\hline
\end{tabular}

a,b,c Means with different superscripts within each row for each parameter are significantly different. $(P \leq 0.05)$.

* TDN (total digestible nutrients) ; * DCP (digestible crude protein)

From these results, it could be noticed that rations containing lentil and chick-pea straws were more nutrients digestibility compared with faba bean straw, This may be due to that, lentil and chick-pea straws had higher $\mathrm{CP}$ and NFE\%, as well as had lower CF\% (Table 1). The higher CP digestibility could be due to the higher nitrogen contained, (Mekasha et al., 2002). Lentil straw is higher in digestibility compared with wheat straw (CRCE, 2009).

Concerning the nutritive values expressed as total digestible nutrients (TDN) and digestible crude protein (DCP), the data of Table (2) clearly indicated that $G 3$ had higher $(P<0.05)$ TDN and DCP content than $G 1$ and G2 and the last one was higher $(P<0.05)$ than $G 1$. This may be attributed to higher nutrients digestibility of G2 and G3 compared to G1, as well as lentil and chick-pea straws were higher CP and NFE content (Table 1), which agreement with Abbeddou et al. (2010) who found appositive correlation between dietary CP content and OM digestibility $(r=0.96, P<0.01)$ across all diets.

Digestibility coefficients of chick-pea straw and clover hay which reported by (Soliman et al., 2005) pointed out to nearly similar feeding values. Abreu and Bruno-Soares (2008) stated that, lentil straw and chick-pea straw had higher OM digestibility compared to faba bean straw, being 48.3 \pm 3.7 , $46.6 \pm 3.4$ and $45.1 \pm 2.5 \%$, respectively. Corresponding values of ME 
recorded 6.2, 6.2 and 6.1 MJ ME/kg. This means that lentil straw and chickpea straw may be used as a good source roughage as faba bean straw.

Feed intake:

Average DM and nutritive values intakes were recorded in Table (3). It could be observed that the differences among the treatments with respect to feed intake were not found.

Table (3): Effect of feeding experimental rations on feed intake by sheep.

\begin{tabular}{|c|c|c|c|c|c|}
\hline Item & G1 & G2 & G3 & Overall mean & SE \\
\hline No. of animals & 8 & 8 & 8 & 8 & \\
\hline \multicolumn{6}{|l|}{ Dry matter intake (DMI): } \\
\hline Concentrate (gm/head/day) & 602 & 616 & 637 & 618.3 & - \\
\hline Roughage (gm/head/day) & 561 & 569 & 578 & 569.3 & - \\
\hline Total DMI (kg) & 1.163 & 1.185 & 1.215 & 1.19 & - \\
\hline TDNI (Kg/head/day) & $0.631^{b}$ & $0.723^{a}$ & $0.775^{\mathrm{a}}$ & 0.710 & \pm 0.09 \\
\hline $\mathrm{CPI}$ (gm/head/day) & $105^{\mathrm{c}}$ & $127^{\mathrm{b}}$ & $137^{\mathrm{a}}$ & 123 & \pm 9.11 \\
\hline DCPI (gm/head/day) & $72^{c}$ & $88^{b}$ & $99^{a}$ & 86.33 & \pm 5.62 \\
\hline
\end{tabular}

a,b,c Means with different superscripts within each row for each parameter are significantly different. ( $P \leq 0.05)$.

${ }^{\star}$ Total digestible nutrient intake, ${ }^{\star \star}$ crude protein intake, ${ }^{\star \star \star}$ digestible crude protein intake. $\mathrm{SE}=$ standard error of the mean.

Consequently the total DMI, which mean that Lentil and Chick-pea straws have approximately the same palatability as that of Faba bean straw, Table (3). CRCE, (2009) stated that, Lentil straw tends to be more palatable than cereal straws. Mekasha et al. (2002) showed that the higher basal DM intake by rams could be attributed to its higher CP content which may have enhanced the efficiency of rumen microorganisms, resulting in improved intake. In addition, the high DM intake could be resulting from the lower fiber content and high CP content in basal diet. So, the total DMI appeared to significantly $(P<0.05)$ higher with $G 2$ and $G 3$. It might be due lower CF\% contents for both Chick-pea and Lentil straw which incorporate it with rate of about $48 \%$ in tested rations. On the other hand, These effects are best accounted by astringency due to tannin binding to salivary proteins, or oral mucous, and due to lesions of the gut (particularly the fore-gut) mucosa (Landau et al., 2000; Silanikove et al., 2001a). Presence of tannins (Ortiz et al., 1993) could be another factor for lowered basal rams' intake. This in agreement with FAO/IAEA(2002) which recommended that general effects of tannins, for example, decrease in vivo nutrient utilization and in particular protein utilization, decrease in growth, decrease in palatability and feed intake or decrease in various enzyme. Tannins are polyphenolic substances with various molecular weights and a variable complexity .

Where, Osama et al. (1990) who told that Polyphenolics including tannins are present in many forage legumes. They may be important in determining feed legume straw quality but there have been no investigation into this.

Concerning TDN and DCP intakes, data of Table (3) indicated that G2 and G3 showed significantly $(P<0.05)$ higher values than the control group G1. This may be attributed to the rations contained chick-pea and lentil 
straws (ration of G2 and G3) had higher TDN and DCP values (Table 2). Also the same trend was observed in case of crude protein intake (CPI), since the highest $(P<0.05)$ value was recorded for $G 3$ followed by $G 2$, while the lowest $(P<0.05) \mathrm{CPI}$ was recorded for $\mathrm{G} 1$. This may be due to that lentil and chickpea straw were higher in CP content than faba bean straw (Table 1).

\section{Rumen parameters}

The values of $\mathrm{pH}$ at zero time were higher then decreased at $3 \mathrm{hrs}$ then tend to increased at $6 \mathrm{hrs}$ after feeding, while TVFA's concentrations were lower values then increased at $3 \mathrm{hrs}$ then tend to decreased at $6 \mathrm{hrs}$ after feeding. This results argument with fermentation system in the rumen.

Table (4): Effect of experimental treatments on some rumen fermentation parameters.

\begin{tabular}{|c|c|c|c|c|c|}
\hline \multirow{2}{*}{ Item } & \multirow{2}{*}{ Time } & \multicolumn{3}{|c|}{ Experimental groups } & \multirow[b]{2}{*}{ SE } \\
\hline & & G1 & G2 & G3 & \\
\hline Animal No. & & 3 & 3 & 3 & \\
\hline \multirow{4}{*}{$\mathrm{pH}$} & $(0 \mathrm{hr})$ & $6.36^{b}$ & $6.50^{\mathrm{ab}}$ & $6.89^{a}$ & \pm 0.130 \\
\hline & (3 hr) & $5.77^{b}$ & $5.99^{b}$ & $6.34^{\mathrm{a}}$ & \pm 0.094 \\
\hline & (6 hr) & $6.30^{b}$ & $6.45^{b}$ & $6.80^{a}$ & \pm 0.057 \\
\hline & Mean & $6.14^{\mathrm{b}}$ & $6.31^{b}$ & $6.67^{a}$ & \\
\hline \multirow{4}{*}{$\begin{array}{l}\mathrm{NH}_{3}-\mathrm{N} \\
(\mathrm{mg} / 100 \mathrm{ml})\end{array}$} & $(0 \mathrm{hr})$ & $18.83^{b}$ & $19.05^{b}$ & $19.83^{a}$ & \pm 0.088 \\
\hline & (3 hr) & $28.57^{\mathrm{b}}$ & $30.17^{\mathrm{D}}$ & $32.32^{a}$ & \pm 0.393 \\
\hline & (6 hr) & 22.26 & 22.12 & 23.42 & \pm 0.280 \\
\hline & Mean & $23.22^{b}$ & $23.78^{b}$ & $25.19^{a}$ & \\
\hline \multirow{4}{*}{$\begin{array}{l}\text { TVFA's } \\
\text { (m.equ./100ml) }\end{array}$} & $(0 \mathrm{hr})$ & 7.68 & 7.72 & 7.77 & \pm 0.210 \\
\hline & (3 hr) & 10.45 & 10.95 & 11.50 & \pm 0.585 \\
\hline & (6 hr) & $8.85^{b}$ & $9.11^{\text {ab }}$ & $9.90^{a}$ & \pm 0.383 \\
\hline & Mean & $8.99^{b}$ & $9.26^{\mathrm{ab}}$ & $9.72^{\mathrm{a}}$ & \\
\hline
\end{tabular}

a and b Means with different superscripts within each row for each parameter are significantly different. ( $\mathrm{P} \leq \mathbf{0 . 0 5})$.

Insignificant differences $(\mathrm{P}>0.05)$ were noticed in rumen $\mathrm{NH}_{3}-\mathrm{N}$ after $6 \mathrm{hrs}$ feeding and TVFA's concentration among the groups at 0 and $3 \mathrm{hrs}$ times after feeding (Table4).

Values of $\mathrm{pH}$ had significant $(\mathrm{P}<0.05)$ higher in $\mathrm{G} 3$ after 3 and $6 \mathrm{hrs}$ feeding than G1 and G2. May be this due to increase $(p<0.05)$ in NH3-N concentration at $3 \mathrm{hr}$ time in rumen liquor collected from G3 relatively with $\mathrm{G} 1$ and G2. In addition to, TVFA's concentration at $6 \mathrm{hr}$ after feeding had $(P<0.05)$ higher for animals fed ration containing Lentil straw (G3) than that containing Faba bean straw (G1).

Data presented in Table (4) indicated that the animals fed rations containing Lentil straw $(G 3)$ tended to significantly $(P<0.05)$ higher in mean of $\mathrm{pH}, \mathrm{NH} 3-\mathrm{N}$ and TVFA's concentration of rumen liquor than that of $\mathrm{G} 1$ which fed ration containing bean straw. Moreover, higher previous values were recorded with G2 than that of G1 with no significant differences. Generally, using Lentil or Chick pea straws in ration formulation of lambs gave higher values of previous rumen parameters than that of using bean straws in its rations. 


\section{Efficiency of nitrogen utilization}

Data of efficiency of nitrogen utilization are shown in Table (5) indicated that the $G 1$ had lower $(P<0.05)$ nitrogen intake $(\mathrm{g} /$ day $)$ compared to G2 and G3. This may be due to the higher CP content for rations containing both lentil and chick-pea straws compared to which included faba bean straw. The same trend was observed for fecal nitrogen and digested nitrogen.

Table (5): Effect of experimental treatments on nitrogen utilization

\begin{tabular}{|l|c|c|c|c|c|}
\hline \multicolumn{1}{|c|}{ Item } & G1 & G2 & G3 & Overall mean & SE \\
\hline Total feed intake (kg) & 1.163 & 1.185 & 1.215 & 1.19 & \pm 0.14 \\
\hline Nitrogen intake (gm/day) & $16.86^{\mathrm{b}}$ & $20.38^{\mathrm{a}}$ & $21.97^{\mathrm{a}}$ & 19.73 & \pm 1.14 \\
\hline Fecal Nitrogen (gm/day) & 5.57 & 6.37 & 7.53 & 6.16 & \pm 0.354 \\
\hline Nitrogen digested (gm/day) & $11.29^{\mathrm{b}}$ & $14.01^{\mathrm{a}}$ & $15.44^{\mathrm{a}}$ & 14.40 & \pm 0.816 \\
\hline Nitrogen urinary (gm/day) & 6.12 & 7.65 & 7.95 & 6.57 & \pm 0.444 \\
\hline Nitrogen balance (gm/day) & $5.17^{\mathrm{b}}$ & $6.36^{\mathrm{a}}$ & $6.49^{\mathrm{a}}$ & 6.16 & \pm 0.46 \\
\hline N retention / N intake ratio \% & $30.66^{\mathrm{a}}$ & $31.21^{\mathrm{b}}$ & $29.54^{\mathrm{b}}$ & 29.98 & \pm 1.39 \\
\hline
\end{tabular}

a,b,c Means with different superscripts within each row for each parameter are significantly different. ( $P \leq 0.05)$.

The values in this table revealed the data collected from the digestion trails period.

Data of nitrogen balance indicated that $N$ retention was higher $(P<0.05)$ for $G 3$ and $G 2$ comparable $G 1$, being $6.49,6.36$ and 5.17 gm/day, respectively.

It is clear that the value of efficiency of $N$ utilization was higher $(P<0.05)$ for $G 3$ compared to $G 2$ and $G 1$; also $G 2$ was higher $(P<0.05)$ efficiency of $N$ utilization than $\mathrm{G} 1$. These may be due to $\mathrm{N}$ intake and $\mathrm{N}$ retention for $\mathrm{G} 3$ and G2 was higher $(P<0.05)$ than $\mathrm{G} 1$. On the other hand, the lower urinary nitrogen obtained in faba bean straw group could be attributed to the higher tannin and fiber content (Mekasha et al., 2002)

Tannin may inhibit the digestion of protein by inactivating microbial enzymes in the rumen (Kumar and Singh, 1984), and by inactivating intestinal enzymes (Silanikove et al., 1994). Tannin can also react directly with dietary proteins, forming complexes resistant to ruminal and post-ruminal degradation (Silanikove et al., 2001b).

\section{Blood parameter}

Data presented in Table (6) showed significantly $(P<0.05)$ increase in blood total protein and albumin concentration for G3 and G2 compared to G1, while insignificant differences were observed in globulin concentration and $A: G$ ratio. It might be due to $G 3$ which recorded the higher value of $N$ intake and $\mathrm{N}$ digested recorded by $\mathrm{G} 3$ and $\mathrm{G} 2$.

So, it could be noticed that the values of blood parameters were affected by $\mathrm{N}$ retention. Consequently, group animals fed ration containing Lentil straw or Chick-pea straw were better fed useful from it, gaving high $\mathrm{N}$ retention and high concentration of some blood parameters. 
Table (6): Effect of experimental treatments on blood parameters

\begin{tabular}{|l|c|c|c|c|c|}
\hline \multicolumn{1}{|c|}{ Item } & G1 & G2 & G3 & Overall mean & SE \\
\hline Total protein, g/dl & $6.97^{\mathrm{b}}$ & $7.85^{\mathrm{a}}$ & $8.47^{\mathrm{a}}$ & 7.76 & \pm 0.025 \\
\hline Albumin, g/dl & $3.77^{\mathrm{b}}$ & $4.25^{\mathrm{a}}$ & $4.74^{\mathrm{a}}$ & 4.25 & \pm 0.06 \\
\hline Globulin, g/dl & 3.2 & 3.6 & 3.73 & 3.51 & \pm 0.10 \\
\hline A/G ratio & 1.18 & 1.31 & 1.37 & 1.29 & \pm 0.12 \\
\hline
\end{tabular}

a,b Means with different superscripts within each row for each parameter are significantly different. $(P \leq 0.05)$.

\section{Growth Performance:}

Table (7) demonstrated that lentil straw group (G3) had the highest $(P<0.05)$ total gain and average daily gain (ADG) followed by chick-pea straw group $(G 2)$, while, faba bean straw group $(G 1)$ had the lowest $(P<0.05)$ one.

In this respect, Soliman et al., (2005) showed that lambs fed clover hay recorded insignificant higher $A D G$ and final live body weight than lambs fed 25 or $50 \%$ chick-pea straw. Also, the same trend in feed intake and feed conversion was obtained. This may be indicated that, chick-pea straw could be substituted clover hay in ruminants ration with almost the same nutritive value, but at relatively lower feed costs. Feed conversion expressed as $\mathrm{kg}$ TDN/kg gain was shown in Table (7) It could be noticed that insignificant differences were observed among the different experimental groups. On the other hand, it was found that $\mathrm{CP}$ and DCP conversion values tended to the highest recorded for $\mathrm{G} 3$ and $\mathrm{G} 2$ compared to $\mathrm{G} 1$. While, the better $(P<0.05)$ DM conversion was recorded for lambs of $G 3$ and $G 2$, and the worst $(P<0.05)$ DM conversion recorded for lambs of $\mathrm{G} 1$.

Table (7): Effect of experimental treatments on total gain (kg), average daily gain $(\mathrm{g})$ and feed conversion

\begin{tabular}{|l|c|c|c|c|c|}
\hline \multicolumn{1}{|c|}{ Item } & G1 & G2 & G3 & $\begin{array}{c}\text { Overall } \\
\text { mean }\end{array}$ & SE \\
\hline No of animal & 8 & 8 & 8 & 8 & \\
\hline Experimental period (day) & 90 & 90 & 90 & 90 & \\
\hline Average initial Weight (kg) & 25.4 & 25.4 & 25.6 & 25.5 & \pm 1.69 \\
\hline Average final Weight (kg) & 38.9 & 40.2 & 41.6 & 40.2 & \pm 2.04 \\
\hline Average total gain (kg) & $13.5^{\mathrm{b}}$ & $14.8^{\mathrm{a}}$ & $16.0^{\mathrm{a}}$ & 14.7 & \pm 0.62 \\
\hline Average daily gain (g) & $150^{\mathrm{b}}$ & $165^{\mathrm{a}}$ & $178^{\mathrm{a}}$ & 164.00 & \pm 0.007 \\
\hline $\begin{array}{l}\text { Feed conversion } \\
\text { Dry Matter (kg DM/ kg gain) }\end{array}$ & $7.75^{\mathrm{a}}$ & $7.18^{\mathrm{b}}$ & $6.82^{\mathrm{b}}$ & 7.25 & \pm 0.312 \\
\hline Total digestible nutrient (kg TDN/ kg gain) & 4.20 & $4.38^{2}$ & 4.35 & 4.31 & \pm 0.182 \\
\hline Crude protein (kg CP/ kg gain) & $0.70^{\mathrm{b}}$ & $0.77^{\mathrm{a}}$ & $0.77^{\mathrm{a}}$ & 0.75 & \pm 0.036 \\
\hline Digestible crude protein (kg DCP/ kg gain) & $0.48^{\mathrm{c}}$ & $0.53^{\mathrm{b}}$ & $0.56^{\mathrm{a}}$ & 0.52 & \pm 0.024 \\
\hline $\begin{array}{l}\text { a,b,c Means with different superscripts } \\
\text { significantly different. (P } \leq \mathbf{0 . 0 5 ) .}\end{array}$ & within & each row for each parameter are \\
\hline
\end{tabular}




\section{Economic efficiency:}

Data presented in Table (8) showed that, animals fed ration containing Lentil straw (G3) had higher feed cost followed by those fed Bean straw (G1), while those fed ration containing Chick pea straw (G2) was the lowest cost to give one kg gain. However, the last one was the most economical efficiency. It could be shown that, higher total return was recorded with G3 owing to higher daily and total gain, but its economical efficiency tended to lower value than the group G2. It was due to higher feed cost.

Table (8): Effect of experimental treatments on economical efficiency

\begin{tabular}{|l|c|c|c|}
\hline \multicolumn{1}{|c|}{ Item } & G1 & G2 & G3 \\
\hline $\begin{array}{l}\text { Average daily feed intake as fed }(\mathrm{gm}): \\
\text { Concentrate feed mixture }\end{array}$ & 665 & 684 & 708 \\
\hline Bean straw & 615 & - & - \\
\hline Chick pea straw & - & 650 & - \\
\hline Lentil straw & - & - & 650 \\
\hline ×Feed cost/head (LE) & 1.229 & 1.189 & 1.387 \\
\hline Feed cost/kg gain (LE) & 8.19 & 7.21 & 7.79 \\
\hline Total feed cost/head (LE) & 110.6 & 107.0 & 124.8 \\
\hline Total return (LE) & 297 & 327 & 352 \\
\hline Economical Efficiency (EE) & 2.69 & 3.05 & 2.82 \\
\hline
\end{tabular}

${ }^{*}$ Price of one ton of CFM=1500 L E, Faba bean straw=375 LE, Chick-pea straw=250LE and Lentil straw=500 LE, price of one $\mathrm{kg}$ gain = 22 LE. (prices during 2009).

Generally, it could be concluded that, such roughages as bean straw, chick-pea straw and lentil straw had to be used with success in formulated rations of growing lambs. Further studies are needed to assess fiber fractions and digestive kinetics of such roughages.

\section{Acknowledgements}

The authors are thankful to Abouel Elaa A.A for the scientific coordination and supply them with lintel and chick pea straws.

\section{REFERENCES}

Abbeddou, S.Rihawi, H.D.Hess, L.Ĩniguez, A.C.Mayer, M.Kreuzer (2010). Nutritional composition of lentil straw, vetch hay, olive leaves, and salt bush leaves and their digestibility as measured in fat-tailed sheeps. Small Ruminant Research (In Press), cited by journal homepage: www.elsevier.com/locate/smallrumres

Abreu. J.M.F. and A.M. Bruno-Soares (2008) Characterization and utilization of rice, legume and rape straws. Lecture in animal Nutrition, Center of International de Hautes Etudes Agronomiques Medetrraneennes (CIHEAM). Zaragoza spain.

Armstronge, W.D. and C.W. Carr. (1964). Physiological Chemistry : Laboratory Directions, $3^{\text {rd }}$ ed. Burges Publishing Co. Minneapolis, Minnesota, USA. 
A. O. A. C. (1995). Association of Official Agricultural Chemists. Official Methods of Analysis. Washington D.C.

Borhami, B. E. A. and M. H. Yacout (2001). Is the animal protein essential for better utilization of plant protein in ruminants? Egypt. J. Nutr. And feeds 4 (Special Issue):25.

Bruno-Soares A.M., J.M.F. Abreu, C.V.M. Guedes, A.A. Dias-da-Silva (2000). Chemical composition, DM and NDF degradation kinetics in rumen of seven legume straws. Animal Feed Science and Technology 83: 75-80

Butterworth, M.H., Mosi, A. (1986). The intake and digestibility by sheep of oat straw and maize stover offered with different levels of noug (Guizotia abyssinica) meal. Anim. Feed Sci. Technol. 16, 99-107.

Conway, E. F (1963). Modification analysis and volumetric error. Rev. ED. Look Wood.London.

CREC (2009). Alternative Feeds for Ruminants. Carrington Research Extension Center, Greg Lardy, Extension Beef Cattle Specialist, NDSU Department of Animal Sciences, Fargo Vern Anderson, Animal Scientist, AS-1182 (Revised), June SITED BY .httplwww.ag.ndsu.edul.

Doumas, B.; W. Wabson and H. Biggs (1971). Albumin standards and measurement of serum with bromocresol green. Clin. Chem., Acta, 31: 87.

Duncan, D.B. (1955) Multiple range and multiple F-test Biometerics, 11-1.

FAO/IAEA, (2002). Quantification of tannins in tree foliage.IAEA-TECDOC, IAEA, Vienna, Austria.

Grasser, L.A.; J.G., Fadel; I. Garnett and E.J. DePeters (1995). Quantity and economic importance of nine selected by-products used in California dairy rations. J. Dairy Sci. 78, 962-971.

Haddad, S.G. and M.Q., Husein (2001). Nutritive value of lentil and vetch straws as compared with alfalfa hay and wheat straw for replacement ewe lambs. Small Ruminant Research 40 :255-260.

Kumar, R. and M. Singh (1984). Tannins: their adverse role in ruminant nutrition. J. Agric. Food Chem. 32, 447-453.

Landau, S.; N., Silanikove; Z., Nitsan; D., Barkai; H., Baram; F.D. Provenza and A. Prevolotsky (2000). Short-term changes in eating patterns explain the effects of condensed tannins on feed intake in heifers. Appl. Anim. Behav. Sci. 69, 199-213.

López, S., D.R. Davies, F.J. Giráldez, M.S. Dhanoa, J. Dijkstra, J.,,France (2005). Assessment of nutritive value of cereal and legume straws based on chemical composition and in vitro digestibility. J. Sci. Food Agric. 85, 1550-1557.

Maynard. E.A; J.K. Looshi; H.S. Hintz and R.G. Warner (1979). Animal Nutrition $\mathrm{Mc} \mathrm{H}-\mathrm{B}$ Book Co. Inc. Ny.

Mekasha,Y; A. Tegegne; A., Yami and N.N. Umunna (2002). Evaluation of non-conventional agro-industrial by-products as supplementary feeds for ruminants: In vitro and metabolism study with sheep. Small Ruminant Research 44 : 25-35. 
Nawar, A. H. (2007). "From Marina to Kom-Ombo: A Note on Poverty in Egypt," Cairo University, Manuscript, August.

Ortiz, L.T., C. Centeno and J. Trevino (1993). Tannins in faba faba bean seeds: effects on the digestion of protein and amino acids in growing chicks. Anim. Feed Sci. Technol. 41, 271-278.

Osama, A. E. , M. H. Ibrahim, M. A. Jones (1990). The Role of legumes in the farming systems of the Mediterranean areas. proceedings of a workshop on the role of legumes in the farming systems of the Mediterranean areas, UNDP/ICARDA, Tunis, June 20-24, 1988

SAS (1998). Stastical Analysis SAS User's Guide: Statistics SAS Institute Inc. Ed. Cary, NC.

Silanikove, N.; N. Gilboa and S. Nitzan (2001a). Effect of polyethylene glycol on rumen volume and retention time of liquid and particulate matter along the digestive tract in goats fed tannin-rich carob leaves (Ceratonia siliqua). Small Ruminant Res. 40, 95-99.

Silanikove, N.; Z. Nitsan and A. Perevolotsky (1994). Effect of polyethylene glycol supplementation on intake and digestion of tannin-containing leaves (Ceratonia siliqua) by sheep. J. Agric. Food Chem. 42, 28442847.

Silanikove, N.; A. Perevolotsky and F.D. Provenza (2001b). Use of tanninbinding chemicals to assay for tannins and their negative postingestive effects in ruminants. Anim. Feed Sci. Technol. 91, 69-81.

Soliman N. A.M.; R. Salama and G.H.M. Zaza (2005). Nutritional evaluation of chick-pea straw as a roughage source in sheep rations. Egyptian J. Nutrition and Feeds, 8 (1) Special Issue:405-416.

Warner, A. C. I (1964). Production of volatile fatty acids in the rumen methods of measurements. Nut. Abst. and Rev., 34: 339.

Zaza, G. H. (2004). Presentation on Agricultural Residues. Expert Consultation on the Utilization of Agricultural Residues. (Workshop Organized by FAO) Cairo, Egypt, 6-8 june. 2004.

Zaza, G. H. M. (2005). Effect of incorporation of biologically treated sugar beet pulp as a non-conventional feed stuff in the diets of growing rabbits. Proceeding of the 4th international Conf. on Rabbits Prod. In hot Climates. Sharm El-Sheik, Egypt. 267 - 274. 
التقييم الغذائي لبعض مخلفات المحاصيل كمصدر للمواد الخشنة في تغذية الحملان إنيان

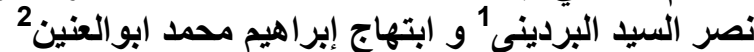

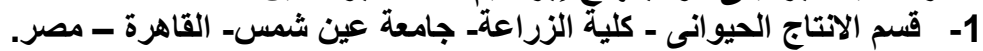

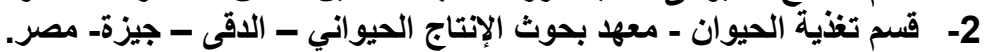

إستخدمت فى هذه الدراسة 24 حولي رحمانى بمتوسط وزن 25 كيلو جرام وعمر أربعة أثهر ، وقد

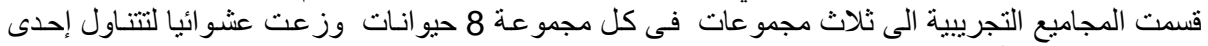

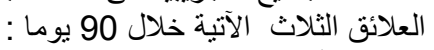

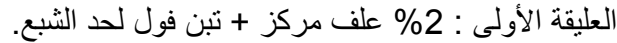

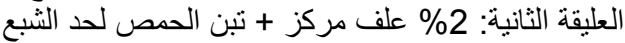

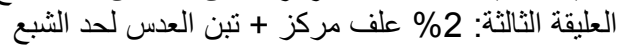

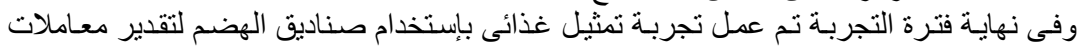

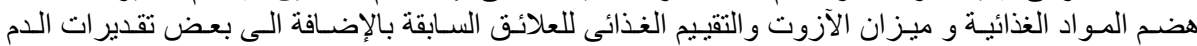

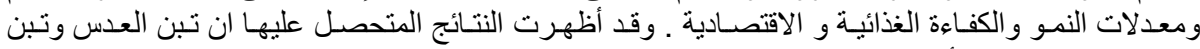

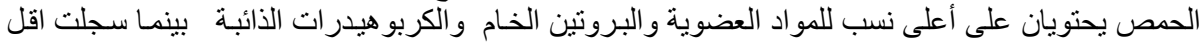

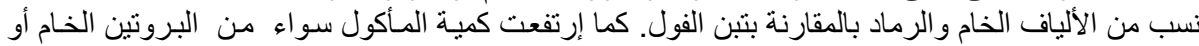

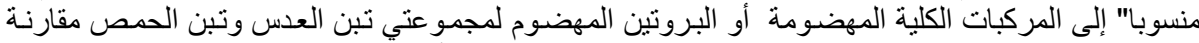

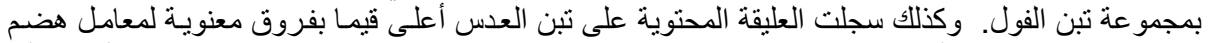

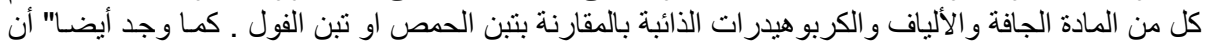

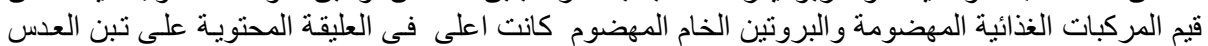

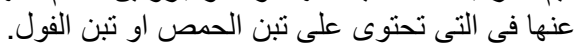

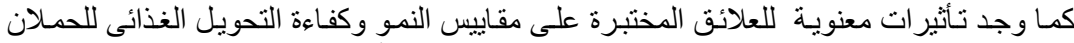

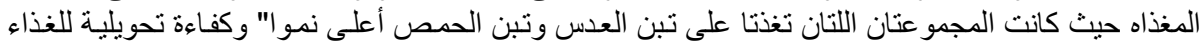

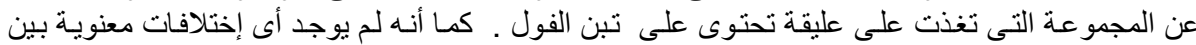

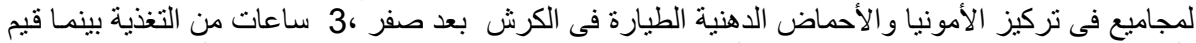

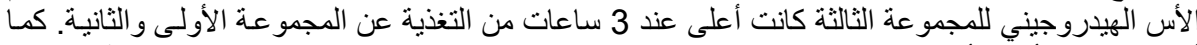

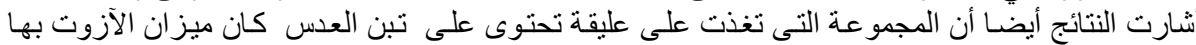

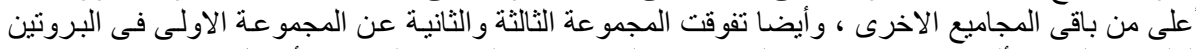

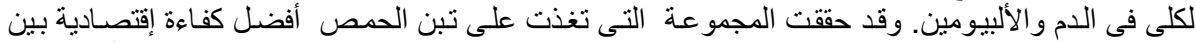

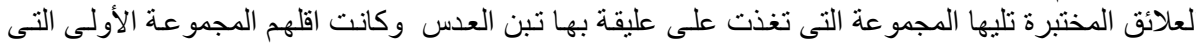

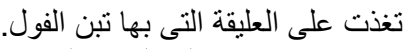

وبناء على النتائج السابقة يمكن التوصية بإستخدام تبن الحمص أو تبن العدس فى علائق الحملان

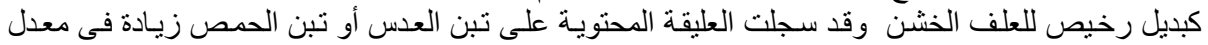

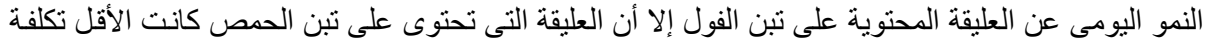

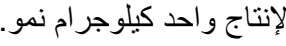

قام بتحكيم البحث

كلية الزراعة - جامعة المنصورة

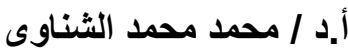

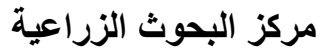

أ.د / كامل عتمان ابراهيم الدين 